\title{
The Possible Role of Curcumin against Changes Caused by Paracetamol in Testis of Adult Albino Rat (Histological, Immunohistochemical and Biochemical Study)
}

\author{
Heba Osama Mohammed and Rasha M. Sabry
}

Department of Anatomy and Embryology, Zagazig University, Egypt

\begin{abstract}
Background: Paracetamol is widely used analgesic which was wrongly thought to be entirely harmless by lots of people. Curcumin has many pharmacological uses such as antibacterial, antiviral, antifungal and anticancer.

The aim of the Work: This study aimed to evaluate the histopathological effects of paracetamol on testicular tissue and how far curcumin can protect testicular tissue from these changes.

Material and Methods: Twenty eight adult rats were used in this work. Rats were equally divided into four groups. Group I: the control group was divided into(subgroup a,b given distilled water ,corn oil respectively ), Group II: was given curcumin $50 \mathrm{mg} \backslash \mathrm{kg}$ body weight, Group III: was given single daily dose of paracetamol 500mg $\backslash \mathrm{kg}$ for five days , Group IV: pretreated with curcumin $50 \mathrm{mg} \backslash \mathrm{kg} \backslash$ body weight for 10 days then received single daily dose of paracetamol $500 \mathrm{mg} \backslash \mathrm{kg}$ in association with curcumin for five days. In the present work, the sperm count, histological and immunohistochemical,biochemical and morphometric studies were evaluated.

Results: Paracetamol caused loss of normal architecture of testicular tissue, wide interstitial spaces, loss of stratal arrangement of germinal epithelium with intercellular spacing. Also,reduction in number of +ve vimentin staining Sertoli cells and marked decrease in number and intensity of PCNA positive cells with increased oxidative stress in testicular tissue. Curcumin protected testis against these alterations.

Conclusion: Curcumin, is effective in reducing paracetamol testicular toxicity in albino rat, by ameliorating oxidative stress, histopathological and immunhistochemical changes and restoring the normal testicular tissue architecture and function and this can be considered for humans.
\end{abstract}

Received: 23 October 2019, Accepted: 28 November 2019

Key Words: Albino rats, curcumin, testis, oxidative stress, paracetamol.

Corresponding Author: Heba Osama Mohammed, M.D., Department of Anatomy and Embryology, Zagazig University, Zagazig, Egypt, Tel.: +2 055 2369963, E-mail: yassin_mekkawy@yahoo.com

ISSN: $1110-0559$, Vol. 43, No.3

\section{INTRODUCTION}

Acetaminophen (ACMP) usually referred to as paracetamol ( $\mathrm{N}$ acetyl para aminophenol) is a white powder or is formed of solid crystals ${ }^{[1]}$. paracetamol is broadly used as a lot of people wrongly thought it is entirely harmless. However, the adminstration of acetaminophen is one of the most common causes of toxicity worldwide ${ }^{[2]}$. Acute over dose of paracetamol might cause toxicity of testis in humans and experimental animals. The first step of paracetamol toxicity is production of the reactive intermediate $\mathrm{N}$-acetyl-p benzoquinone imine (NAPQI) by cytochorom $\mathrm{P} 450$ which is removed by conjugation to glutathione in the therapeutic doses, so the higher doses of paracetamol lead to drop of cellular content GSH which allows NAPQI to combine with the cellular proteins and induction of lipid peroxidation, leading to toxicity. Paracetamol-induced toxicity could also be due to hepatic-derived paracetamol metabolites; particularly GSH conjugates ${ }^{[3]}$. The human testis is a target organ for injury caused from exposure to therapeutic and toxic agents in the enviroment. There are a lot of probable mechanisms and signs of toxic damage to spermatogenesis as pituitary-hypothalamic or sex hormonal affection which could affect the process of spermatogenesis and chemical exposure of the seminal fluid, causing functional or structural disruption of sperm cells ${ }^{[4]}$ Inside the testes, Leydig, Sertoli cells, and the germ cells themselves are the target cells for toxins ${ }^{[5]}$.

Curcuma longa (turmeric), a yellow food color and a component of curry powder, has been used for long time in traditional medicine of Asia as a tonic for stomach and blood filter, and for skin disease treatment and healing of wound ${ }^{[6]}$. Lately, it is focused on the prophylactic role of products of plants or medicinal plants having antioxidant effects as curcumin for therapeutic purposes in reduction of free radical-induced tissue damage ${ }^{[7,8]}$. Curcumin has many pharmacological uses such as antibacterial, antiviral, antifungal ${ }^{[9]}$, anticancer ${ }^{[10]}$, anti-inflammatory ${ }^{[11]}$ and antioxidant $^{[12]}$

Subsequently, we aimed in this study to complete this way by searching more points. To our knowledge, potential 
prophylactic and protective role of curcumin treatment prior and in concomitant with paracetamol adminstration has not been established. So we aimed to explore its role with an emphasis on its impacts on histomorphological, biochemical and morphometrical changes of testicular tissue if given before and in association with administration of paracetamol.

\section{MATERIALS AND METHODS}

\subsection{Materials}

\subsubsection{Chemicals}

Paracetamol used in this study obtained from pharmaceutical company in Egypt (El-Nile Pharmaceutical Company) . Curcumin was purchased from Sigma-Aldrich .Both paracetamol and curcumin were prepared by dissolving in distilled water and corn oil respectively and were given orally via gastric gavage.

\subsubsection{Animals}

In this study, twenty eight Male Albino rats weighing approximately 180-200 were g obtained from animal house of Zagazig faculty of medicine. The animals were housed in clean plastic cages in a temperature- and humiditycontrolled facility with a constant $12 \mathrm{~h} \mathrm{light/dark}$ cycle. Food and tap water were offered ad-libitum during the study period. All treatments were started after two weeks of acclimatization. The study was carried out according to the guidelines ZU-IACUC which follow the guidelines contained in the guide for the care and use of laboratory animals $8^{\text {th }}$ Edition 2011 (No.ZU-IACUC/F/105/2018).

\subsubsection{Experimental Design}

The rats were randomly divided into four groups, each containing seven animals

Group I (control group): The rats in this group are further subdivided into:

Group (a) $\mathrm{n}=3$ : received $2 \mathrm{ml}$ distilled water only via gastric gavage for 15 days.

Group (b) $\mathrm{n}=4$ : received $2 \mathrm{ml}$ corn oil only via gastric gavage for 15 days.

Group II (curcumin group): The rats were received curcumin $50 \mathrm{mg} \backslash \mathrm{kg} \backslash$ body weight dissolved in corn oil via gasrtic gavage for 15 days.

Group III ( paracetamol group): The animals were received single daily dose of paracetamol $500 \mathrm{mg} \backslash \mathrm{kg} \backslash$ body weight dissolved in distilled water via gastric gavage in the last 5 days of the experiment.

Group IV(paracetamol +curcumin): The rats in this group pretreated with curcumin $50 \mathrm{mg} \backslash \mathrm{kg} \backslash$ body weight for 10 days then received single daily dose of paracetamol $500 \mathrm{mg} \mathrm{kg}$ on 10 th day of experiment for 5 days in association with curcumin.
Throughout the experiment, animals were observed for any mortality. Doses of paracetamol and curcumin were according to ${ }^{[12]}$.

\subsection{Methods}

\subsubsection{Body Weight and Testicular Weight Measurements}

Body weight was measured before beginning and every day in the experiment for follow up and dose calculation for each rat. But at the end of the experiment, and testicular weight were statistically analyzed.

\subsubsection{Biochemical Studies}

\section{Determination of Serum Testosterone Level}

Blood samples were withdrawn from the tail vein from all animals at time of sacrifice .Each sample was allowed to coagulate and then centrifuged at $1000 \mathrm{xg}$ for $20 \mathrm{~min}$. The separated sera were used for the estimation of serum level of testosterone hormone Serum levels were identified by (The BioVendor Mouse /Rat Testosterone by enzymelinked immunosorbent assay (ELISA), RTC001R ${ }^{[13]}$.

\section{Oxidative Stress Markers Study}

From each rat the Lt testis was homogenized in icecold $50 \mathrm{mM}$ sodium phosphate buffer ( $\mathrm{pH}$ 7.4) containing $0.1 \mathrm{mM}$ ethylene diamine tetraacetic acid (EDTA). The supernatant was separated by centrifugation at $1000 \mathrm{~g}$ for $20 \mathrm{~min}$ at $4 \mathrm{C}$. The supernatant was used for the analyzes of MDA, Glutathione peroxidase and superoxide dismutase.

MDA, as a marker of lipid peroxidation, was measured colorimetrically in testis homogenate according to ${ }^{[14]}$. With the use of a commercially available kit (Biodiagnostic, Cairo, Egypt). Thiobarbituric acid reacts with MDA in acidic medium at $90^{\circ} \mathrm{C}$ for $30 \mathrm{~min}$ to form thiobarbituric acidereactive product, and the absorbance of the resultant pink product can be measured at $534 \mathrm{~nm}$.

Superoxide dimutase (SODs) it was measured colorimetrically in testis homogenate according to ${ }^{[15]}$ with the use of a commercially available kit (Biodiagnostic, Cairo, Egypt).

Glutathione perioxidase it was measured colorimetrically in testis homogenate according to the method of ${ }^{[16]}$ with the use of a commercially available kit (Biodiagnostic, Cairo, Egypt).

\subsubsection{Semen Analysis}

At the time of laparotomy, the epididymis was carefully separated from the testes. The cauda was dissected gently by using a scalpel blade to allow sperms coming out from cauda epididymis and then was dipped into a petri dish (35 mm) containing Phosphate Buffered Saline(PBS) incubated in $37^{\circ} \mathrm{C}$ for 10 minutes. Sperms were incubated for approximately $3 \mathrm{~min}$ and then the collected samples were diluted with distilled water in a ratio 1:20. Ten micron 
of it was taken by micropipette and put on hemocytometer slide for detecting motility and count of the sperms under $\times 400$ magnifications $^{[17]}$ by light microscopy. Sperms heads were counted, under the microscope, in the five large squares, and then multiplied by five to get number of sperms per counting area. The average number of sperms was multiplied by ten thousands to get the number of sperm per $\mathrm{ml}$ of diluted sample. The number of sperms per $\mathrm{ml}$ in the original sample was calculated by multiplying the previous count in the dilution factor. The next equation was used to get the concentration of the original sperm sample in the term of numbers/ $\mathrm{ml}$.

Concentration $/ \mathrm{ml}=$ (dilution factor) (count in 5 squares) $(0.05 \times 106)^{[18]}$

\subsubsection{Light Microscope Examination}

At the end of the experiment, the rats were anaesthetized with thiopental sodium $(60 \quad \mathrm{mg} \backslash \mathrm{kg}$ by.intraperitoneal injection $)^{[19,20]}$. The abdomen was opened, and the testis and epididymis were carefully dissected. The right testes were fixed in a $10 \%$ neutral buffered formalin solution. After fixation, specimens had been processed for paraffin embedding.

\subsubsection{Histopathological Examination}

Specimens of testes from each rat were weighted then were fixed in buffered neutral formaldehyde $10 \%$ and preserved to form paraffin section and The testis had been sectioned at a thickness of 5 microns for histological staining. with haematoxylin and Eosin according to ${ }^{[21]}$.

\subsubsection{Immunohistochemical Study}

Proliferating cell nuclear antigen (PCNA) is an intranuclear polypeptide that is incorporated in DNA replication, repair and excision. Its expression is indicator to cell proliferation ${ }^{[22]}$. Since spermatogenesis is a complex cell cycle of rapidly proliferating cells ending with liberation of sperms, PCNA was used in this study to quantitatively analyze spermatogenesis. Immunohistochemical staining was carried out by using primary antiserum to PCNA (Clone PC 10, DAKO A/S Denmark). The primary antibody was diluted in Trisbufferd saline with a dilution of 1:50, as determined by the data sheet. The sections were incubated with the primary antibody overnight at $+4^{\circ} \mathrm{C}$. Enough Biotinylated secondary antibodies were applied to cover specimen then the binding of the primary antibody was observed using a commercial avidinbiotin-peroxidase detection system recommended by the manufacturer (DAKO, Carpenteria, USA). A mouse monoclonal antibody was applied in place of the primary antibody to act as a negative control. Sections from the small intestine were used as a positive control. Then the slides were stained with diaminobenzene (DAB) as the chromogen and counter stained with hematoxylin then slide dehydrated in $95 \%$ ethanol, cleared in xylene then cover slips were mounted using two drop of DPX mounting medium ${ }^{[23]}$.
Primary antibodies obtained from Santa Cruz Biotechnology Inc. (Santa Cruz, California, USA) antivimentin (1:50 dilution) Sections were then treated with avidin- biotin-peroxidase reagent for $30 \mathrm{~min}$ (Dako, Japan Ltd, Kyoto, Japan). PBS $0.01 \mathrm{mmol} / 1$ was applied instead of primary antibodies as a negative control. Positive control : human rhabdosarcoma cell line JR $1^{[24]}$.

The prepared specimens were examined in the light microscope unit, Department of Anatomy and Embryology, Faculty of Medicine, Zagazig University.

\subsubsection{Morphometric Study}

Seminiferous tubular diameter and the number of PCNA strong positive cells/tubule were determined by using Leica Application Suite (LAS version 4.12.0 (Build:86) copyright c 2003-2017,Leica Microsystems (Switzer-land) Limited. Leica Microsystems CMS GmbH. The tubular diameter of about one hundred nearly circular seminiferous tubules for each group were measured at $\times 100$ magnification. Two perpendicular diameters were taken then the mean of them was taken for each tubule. The number of PCNA strong positive cells/tubule was measured at $\times 400$ magnification. Area percentage of vimentin positive reaction was measured at $x 400$ magnification by using FIJI program. This was done at $\mathrm{x} 400$. Five fields per slide and five slides per animal were evaluated fot each parameter.

\subsubsection{Statistical Analysis}

Statistical analysis was carried out using Graph Pad Prism 5 "Graph Pad Software, San Diego, USA" and were performed using (ANOVA) test followed by Student -Newman-Keuls post hoc test with the value of $p<0.05$ considered statistically significance. The obtained data were stated as mean values and SE.

\section{RESULTS}

\subsection{Survival, Body Weight and Testicular Weight Results}

No occurance of mortality among rats during the experimental period. There was slightly non statistically significant decreased in the body weight or testicular weight in paracetamol or paracetamol \&curcumin groups in comparison with control groups (Table 1).

\subsection{Biochemical Results}

\subsubsection{Serum Total Testosterone Level}

According to serum testosterone level there was significant decrease in paracetamol treated group whichwas significantly but slightly increased by curcumin in paracetamol\&curcumin group but still lower than $\operatorname{control}(P<0.05)$ (Table 1, Figure 1). 


\subsubsection{Oxidative Stress Markers Results}

MDA values were significantly higher in the paracetamol treated group than in the control group, but these values decreased significantly with curcumin treatment. Moreover, MDA values of paracetamol+curcumin treated group were still significantly different from control group SOD and GPx values were significantly decrease in the paracetamol group than in the control group (Table 1, Figure 2). However, SOD and GPx values were significantly increased in the paracetamol+curcumin treated group as comparing with their significantly decreased values in paracetamol group. (Table 1, Figures 3A,B).

\subsection{Semen Analysis Results}

According to sperm count and motility, there was significant decrease in sperm count and motility in paracetamol group in comparison with control and curcumin groups and statistically significant increase occurred in paracetamol \&curcumin group $(P<0.05)$. (Table1, Figures 4A,B).

\subsection{Histopathological Results}

\subsection{1. $H \& E$}

\section{Control groups}

On examination of both control and curcumin treated groups, there were no histological differences detected. control groups showed normal testicular architecture with regular seminiferous tubules and narrow interstitial spaces (Figure 5A), seminiferous tubules were lined by stratified germinal epithelium consisting of germ cells in various stages, spermatogonia with dark oval nuclei and rested on basal lamina, spermatocytes, round spermatids and many elongated spermatids. sertoli cells with pyramidal vesicular nucleus and prominent nucleolus. Tubular lumina were filled with flagella of mature sperms. Additionally, Leydig cells were present in interstitial spaces (Figures 5B,5C).

\section{Paracetamol Treated Group}

Examination of testicular sections of paracetamol treated group showed loss of normal architecture of testicular tissue with wide spaces between tubules, sloughing of basal lamina of many seminiferous tubules from lamina propria (Figure 6A), loss of stratal arrangement of germinal epithelium with wide intercellular separation, occluded lumen with vacuolated oesinophilic substance and wide interstitial space filled with oesinophilic material (Figures 6B,6C). Sertoli cell showed pale nuclei and distorted and destructed cytoplasmic extension, few elongated spermatids and round spermatids and few flagella of mature sperms in lumina. Wide interstitial spaces had Leydig cells with oval vesicular nuclei and eosinophilic cytoplasm, infiltration with dark stained inflammatory cells and dilated congested blood vessel (Figure 7A,B)

\section{Paracetamol and Curcumin Treated Group}

Paracetamol and curcumin treated group showed preservation of testicular architecture with relatively regular seminiferous tubules and narrower interstitial spaces (Figure 8A), germinal epithelium showed better arranged germinal strata, less amount of exudate in interstitial tissue with Leydig cells having vesicular nucleus (Figure 8B). Spermatogonia rested on basal lamina and closely related to each other with little intercellular spacing, spermatids in various stages of spermiogenesis were present as rounded spermatids, elongated spermatids embedded in cytoplasmic extensions of sertoli cells, lumina were full of flagella of mature sperms (Figure 8C).

\subsubsection{Immunohistochemical Results}

\section{Vimentin}

In both control and curcumin treated groups, vimentin filaments positive reaction within sertoli cells was concentrated around nucleus (perinuclear) in basal part of the cell then radiating apically toward the apical part of the cell (Figure 9). In paracetamol treated group the number of sertoli cells presenting positive vimentin reaction was reduced with disturbed apical cytoplasmic extensions and marked irregularity of basement membrane of seminiferous tubule (Figure $10 \mathrm{~A}, \mathrm{~B}$ ). These findings were relatively less in paracetamol and curcumin treated group, as many sertoli cells showed normally distributed vimentin filaments perinuclear and apical with cytoplasmic extensions. Regular basement membrane of seminiferous tubule was detected (Figure 11).

\section{PCNA Immunostaining}

According to PCNA immunostaining in control group (Figure 12A) PCNA positive cells were basal germ cells, sections of testicular tissue of paracetamol group revealed marked decrease in number and intensity of PCNA positive cells (Figure 12B), while there was increase in PCNA positive cells in paracetamol\&curcumin group .Moreover some germ cells other than spermatogonia and primary spermatocytes showed faint positivity for PCNA (Figure 12C),

\subsection{Morphometrical Results}

Regarding the number of PCNA strong positive cells / tubule, by comparing paired columns by Student-NewmanKeuls post hoc test there was significant difference between paracetamol group versus control,curcumin treatedand paracetamol \& curcumin groups (Significant $P<0.05$ ), also there was significant difference between paracetamol versus paracetamol and curcumin groups (Significant $P<0.05$ ) (Table 2, Figure13)

According to tubular diameter, ANOVA test showing significant increase in paracetamol group and nonsignificant increase in paracetamol and curcumin in 
comparison with control and curcumin groups $P<0.05$. However significant decrease occurred in paracetamol and curcumin group in comparison with paracetamol group (Table 2, Figure14).

Regarding area \% of vimentin positive staining there was highly significant decrease in area $\%$ in paracetamol group in comparison with both control and curcumin groups. Also there was highly statistically significant increase in paracetamol and curcumin group in comparison with paracetamol group (Table 2, Figure 15).

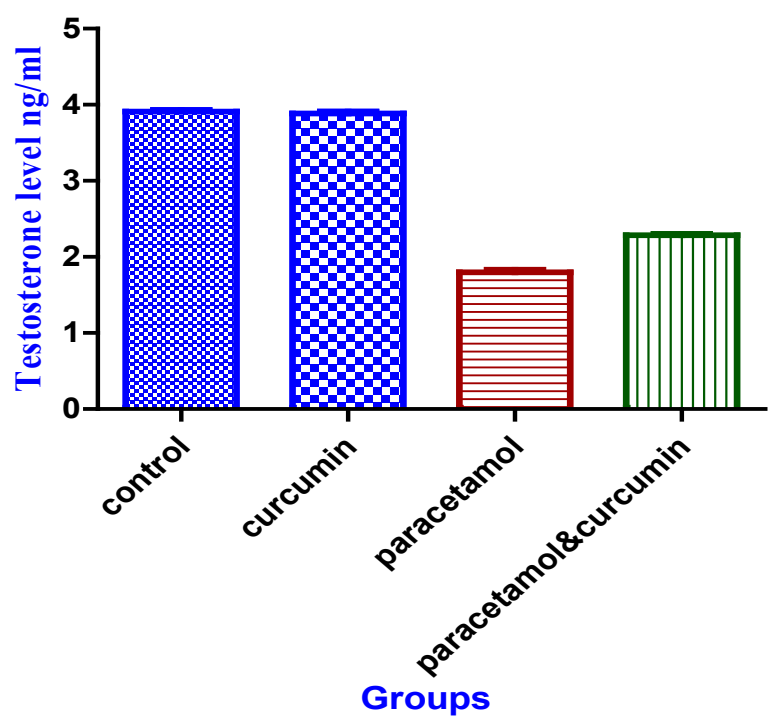

Fig. 1: Bar chart showing serum testosterone level (ng/ ml) among different groups

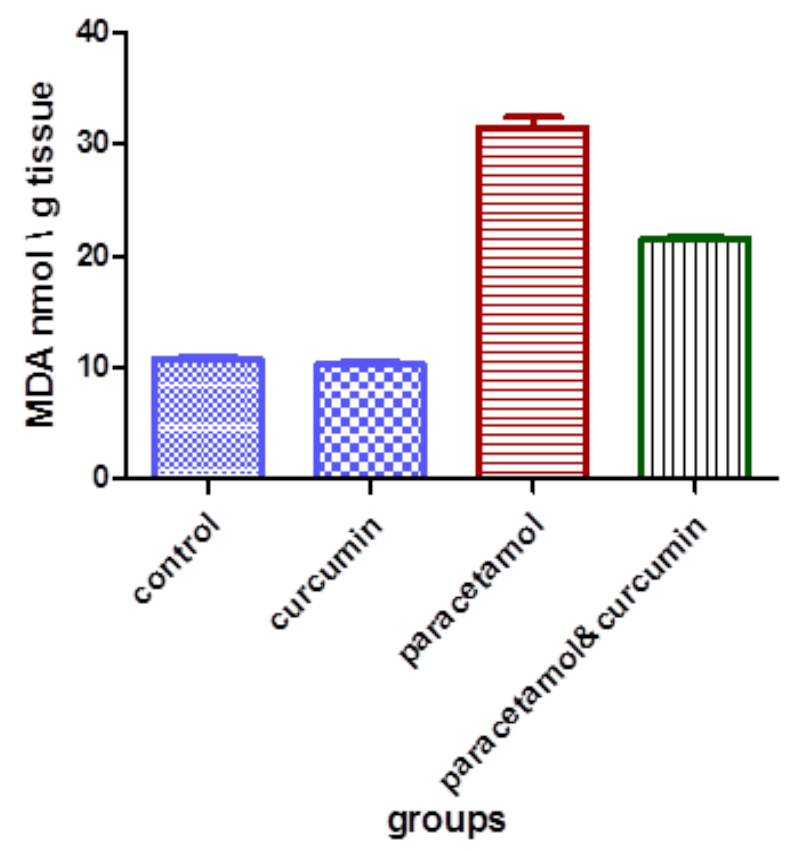

Fig. 2: Bar Chart showing Level of MDA nmol/g tissue among different groups

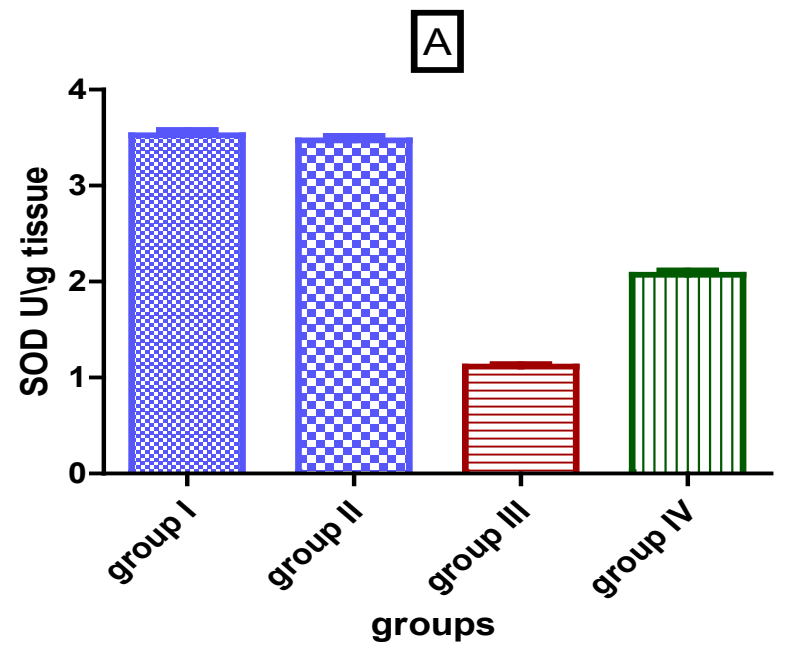

Fig. 3A: Bar chart showing level of superoxide Dismutase (SOD) $\mathrm{U} \backslash \mathrm{g}$ tissue among different groups

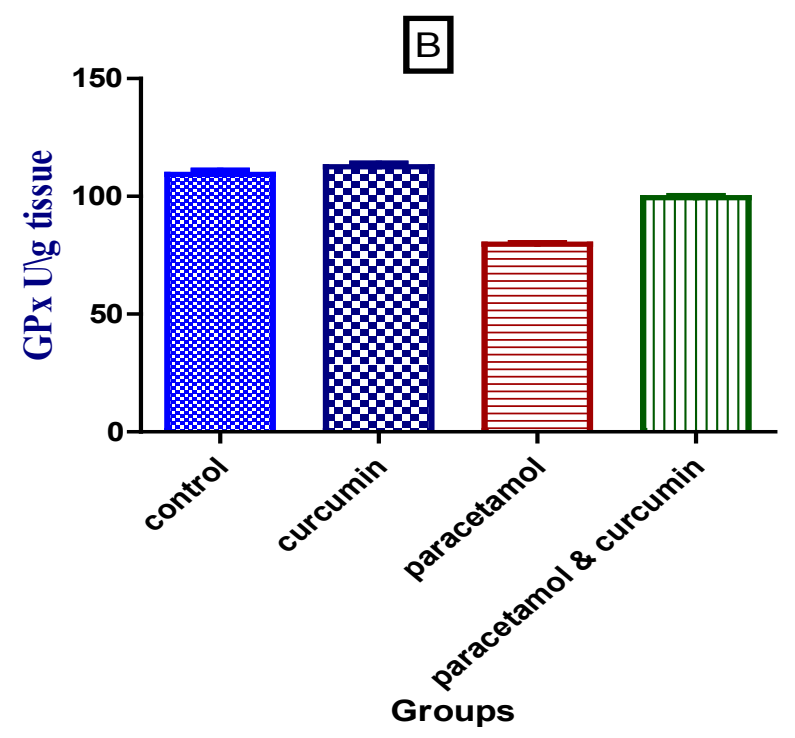

Fig. 3B: Bar chart showing level of GPx U\g tissue among different groups

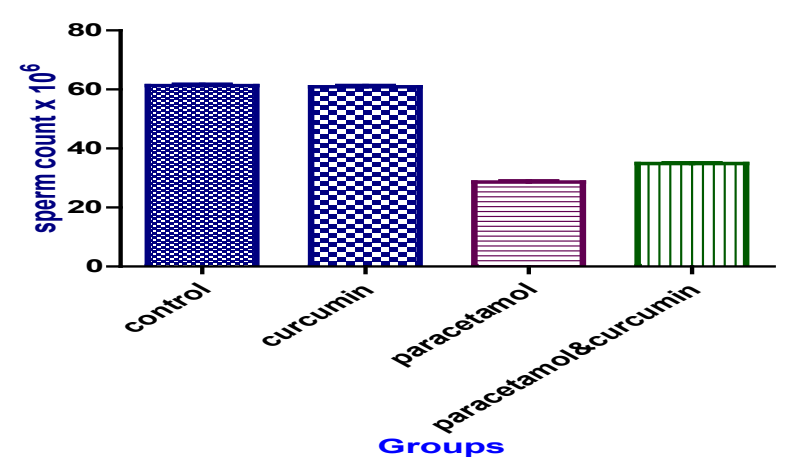

Fig. 4A: Bar chart showing sperm count of different groups 


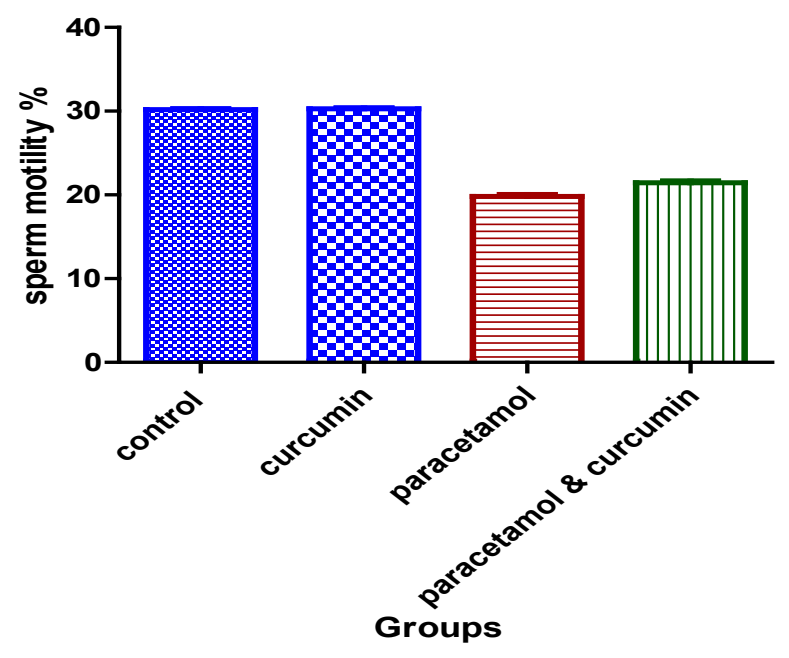

Fig. 4B: Bar chart showing sperm motility $\%$ of different groups
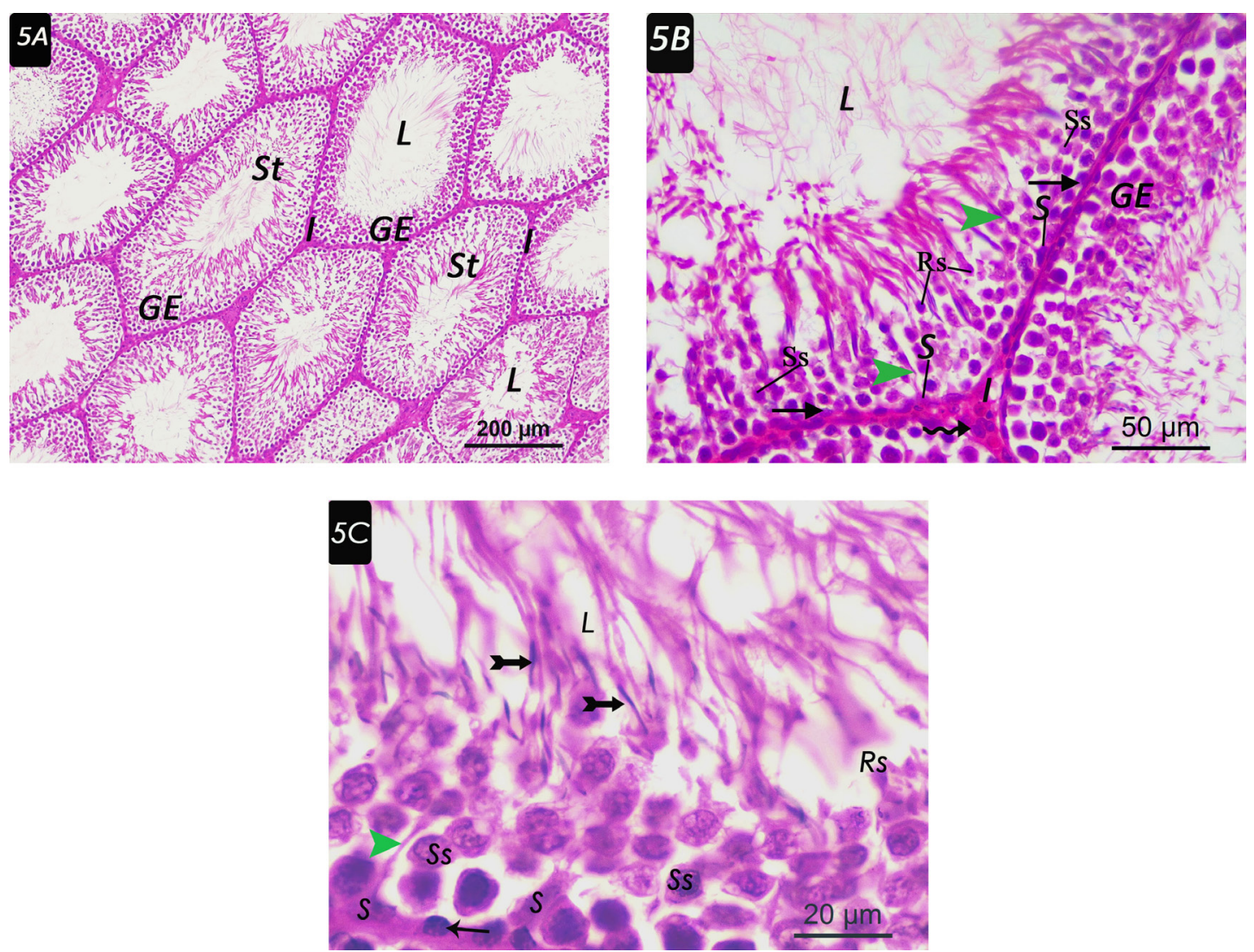

Fig. 5: Photomicrographs of testicular sections of adult male rats in the control group showing (5A) multiple seminiferous tubules ( St) with regular outlines, lined by germinal epithelium (GE), narrow interstitial spaces ( I) and lumen (L) filled with sperm flagella (H\&E, Scale bar: 200 $\mu \mathrm{m})$. (5B): Well-arranged germinal epithelium (GE) lining tubules with spermatogonia (arrow). Sertoli cells (S) appear pyramidal with well-formed cytoplasmic extensions (green arrow head). Lumen (L) is full of sperm flagella, interstial space (I) is containing Lyedig cells with vesicular nuclei (zigzag arrow) (H\&E, Scale bar: $50 \mu \mathrm{m})$. (5C): Spermatogonium resting on basement membrane (arrow),spermatocyte (Ss),round spermatids (Rs) toward lumen(L) and many elongated spermatids(tailed arrow). Sertoli cell (S) with vesicular nucleus and well-formed cytoplasmic extension (green arrow head) are detected. (H\&E oil immersion, Scale bar: $20 \mu \mathrm{m})$ 

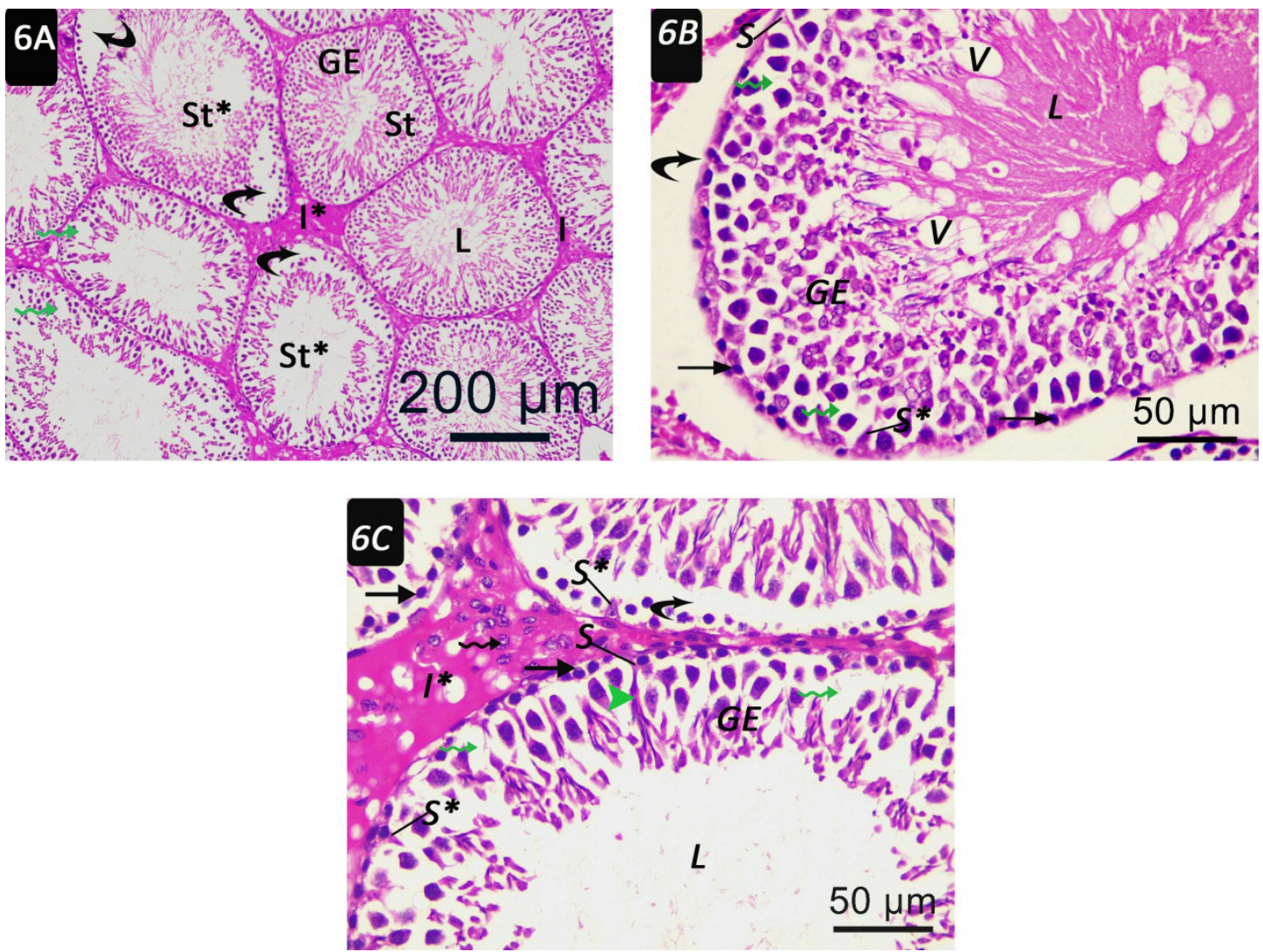

Fig. 6: Photomicrographs of testicular sections of adult male rats in paracetamol treated group showing (6A) some seminiferous tubules (St) lined with wellarranged strata of germinal epithelium (GE), many other tubules ( $\left.\mathrm{St}^{*}\right)$ were depleted of most of spermatogenic cells, with sloughed germinal epithelium(curved arrow), there were empty spaces in between germ layers ( green zigzag arrow ) and thick interstitial tissue (I*) (H\&E , Scale bar: 200 $\mu$ m ). (6B) seminiferous tubule has sloughed basement membrane (curved arrow), wide separation in between germ layers (green zigzag arrow), spermatogonium (arrow) resting on basement membrane. Some Sertoli cells(S) appear with normal cytoplasmic extension (green arrow head), others ( $\mathrm{S}^{*}$ ) with distorted nuclei. Note, occluded lumen (L) with vacuolated oesinophilic substance (V) (H\&E, Scale bar: $50 \mu \mathrm{m})$. (6C) seminiferous tubules have few germinal layers with sloughing from basement membrane (curved arrow) and wide separation within germinal layers (green zigzag arrow), few mature sperm flagella in lumen (L), spermatogonia (arrow), resting on basement membrane thick interstitial tissue (I*) filled with exudate containing many Leydig cells (zigzag arrow). Some Sertoli cells (S) appear with normal cytoplasmic extension(green arrow head) (H\&E, Scale bar: $50 \mu \mathrm{m})$
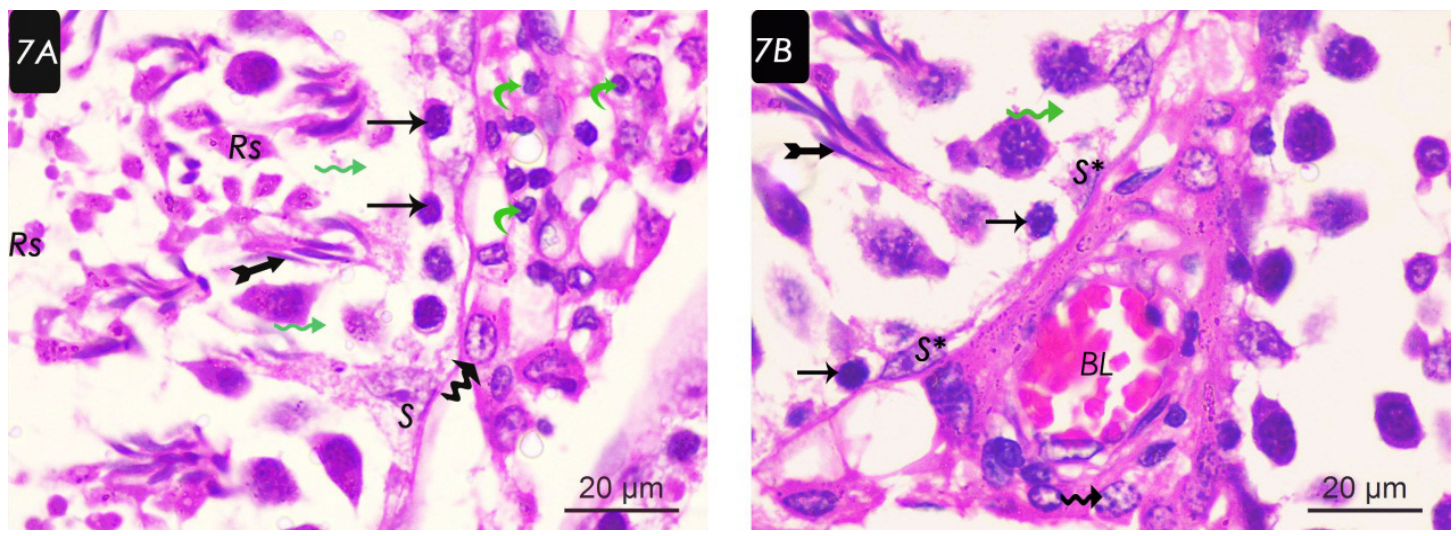

Fig. 7: Photomicrographs of testicular sections of adult male rats in paracetamol treated group showing (7A) part of a seminiferous tubule with distorted germ cells and wide separation in between (green zigzag arrow), Sertoli cell (S) with pale nucleus, spermatogonia (arrows) have oval dark stained nuclei, few elongated spermatids (tailed arrows) are embedded in cytoplasmic extensions of Sertoli cell and few round spermatids (Rs). Interstitial space shows Leydig cells (zigzag arrow) have oval vesicular nucleus and eosinophilic cytoplasm, infiltration with dark stained inflammatory cells (curved green arrows) is also seen. (7B) Few spermatogonia (arrow), distorted widely separated germ cells (green zigzag arrow), Sertoli (S*) with small pale nuclei, elongated spermatid (tailed arrow). Interstial tissue shows dilated congested blood vessel (BL) and Leydig cells (zigzag arrow) (H\&E oil immersion, Scale bar 20 $\mu \mathrm{m})$ 

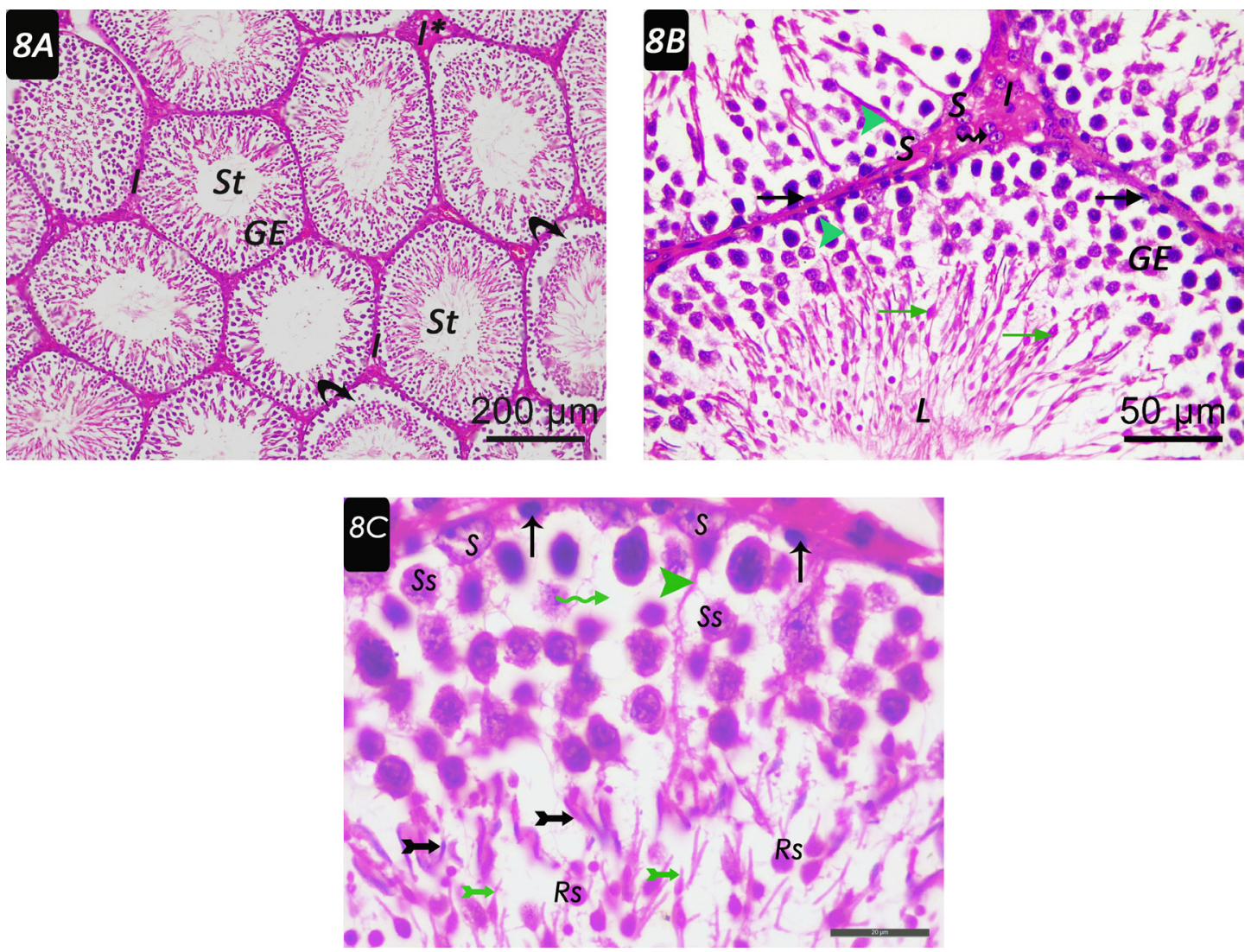

Fig. 8: Photomicrographs of testicular sections of adult male rats in paracetamol and curcumin treated group showing (8A): regular seminiferous tubules (St) lined by germinal epithelium (GE), narrow interstitial tissue (I) in most areas and wider interstitial tissue (I*) in few areas. Few tubules have sloughed germina epithelium (curved arrow) (H\&E, Scale bar: $200 \mu \mathrm{m}$ ). (8B) well organized germ cells into strata (GE) beside well-formed cytoplasmic extensions (green arrow head) of Sertoli cells (S), round spermatids (green arrow), lumen (L) is full of mature sperms flagella. Interstial tissue (I) containing Leydig cells (zigzag arrow) (H\&E,Scale bar: $50 \mu \mathrm{m})$. (8C) seminiferous tubule shows better organization of germ layers and minimal separation in between them (green zigzag arrow). Sertoli cell (S) with well-formed cytoplasmic extension (green arrow head). Dark stained spermatogonium resting on basement membrane (arrow) spermatocytes (Sc), round spermatids (Rs) lumen (L) and many elongated spermatids (tailed arrow) and Spermatids with beginning of tail formation (green

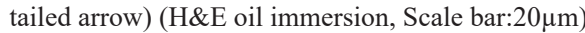

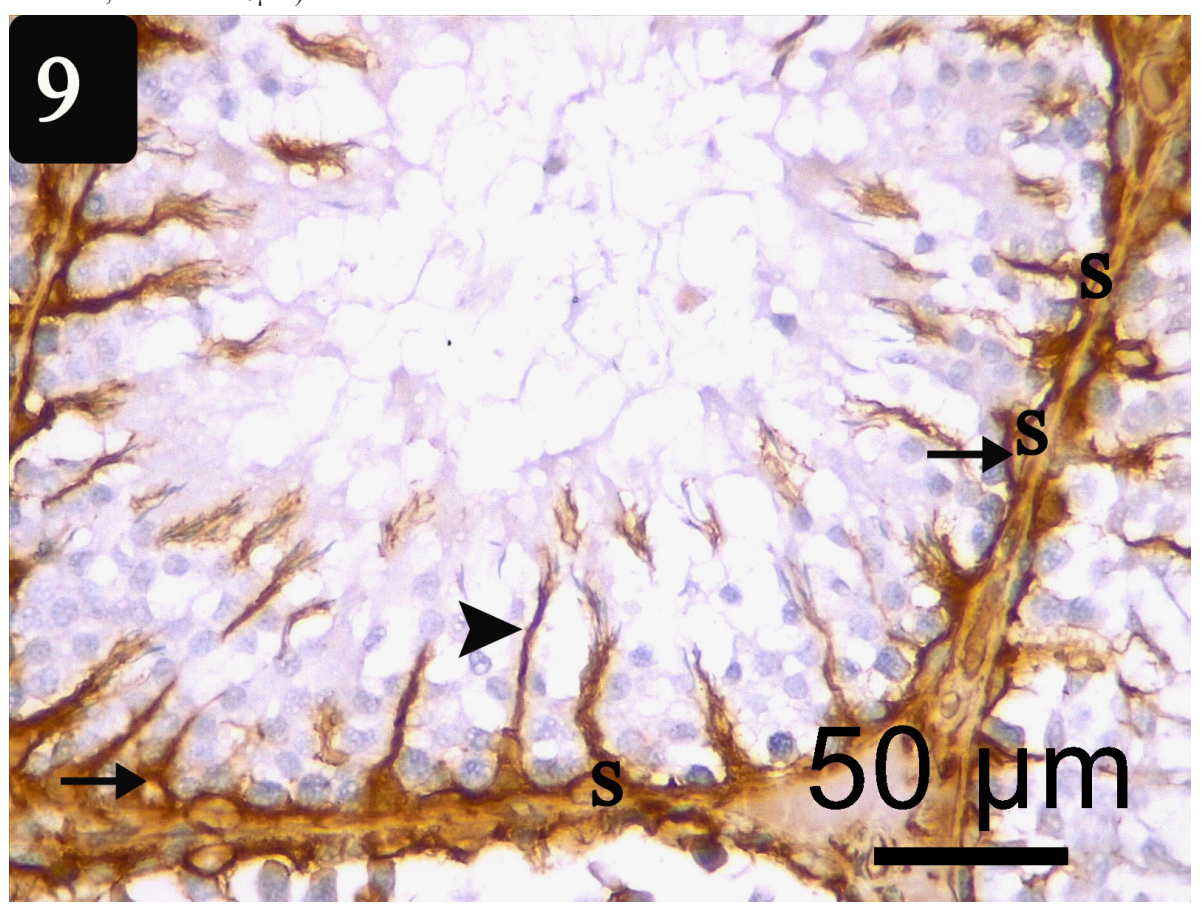

Fig. 9: Photomicrograph of a section in testicular tissue of adult male rat in control group showing appearance of sertoli vimentin filaments (immunohistochemical staining), Sertoli cell (S) has perinuclear positivity (arrow) and in cytoplasmic extensions (arrow head ) (Vimentin immunohistochemistry, Scale bar: $50 \mu \mathrm{m}$ ) 

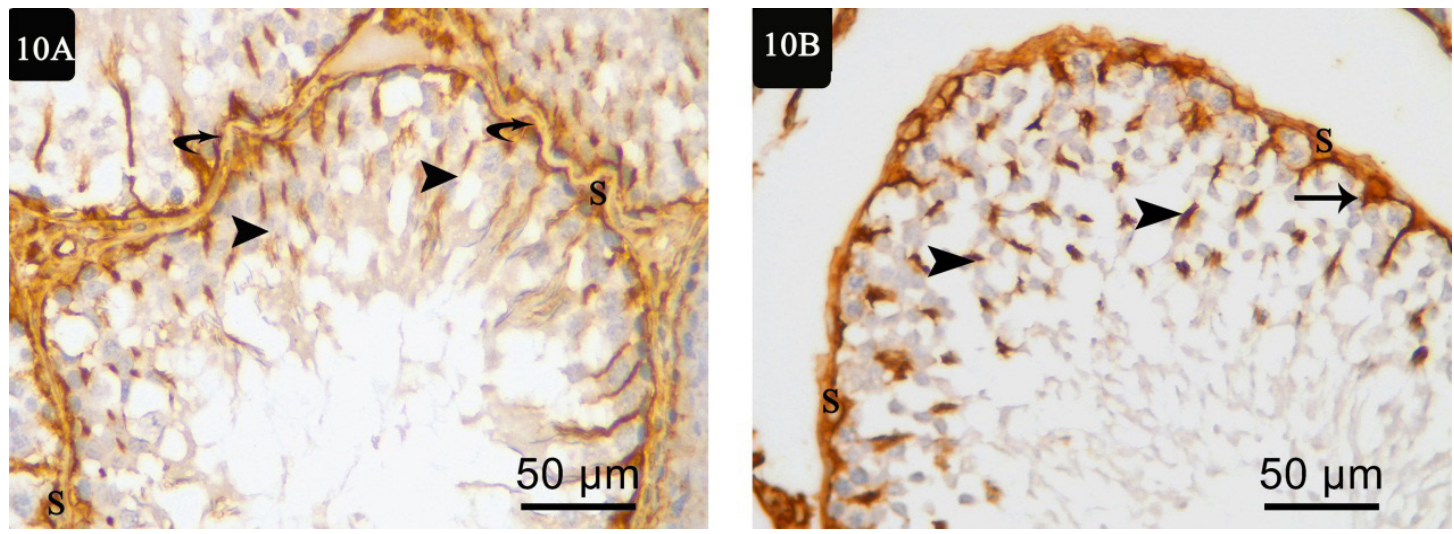

Fig. 10: Photomicrographs of a section in testicular tissue of adult albino rats in paracetamol treated group shows, (10A) marked decrease in number of Sertoli cells showing positive reaction (S), fragmentation of cytoplasmic extensions (arrow head) and irregular basal lamina (curved arrows). (10B) marked decrease in number of Sertoli cells showing positive reaction (S), fragmentation of cytoplasmic extensions (arrow head) and its perinuclear positivity is distorted (arrow), (Vimentin immunohistochemistry, Scale bar: $50 \mu \mathrm{m}$ )

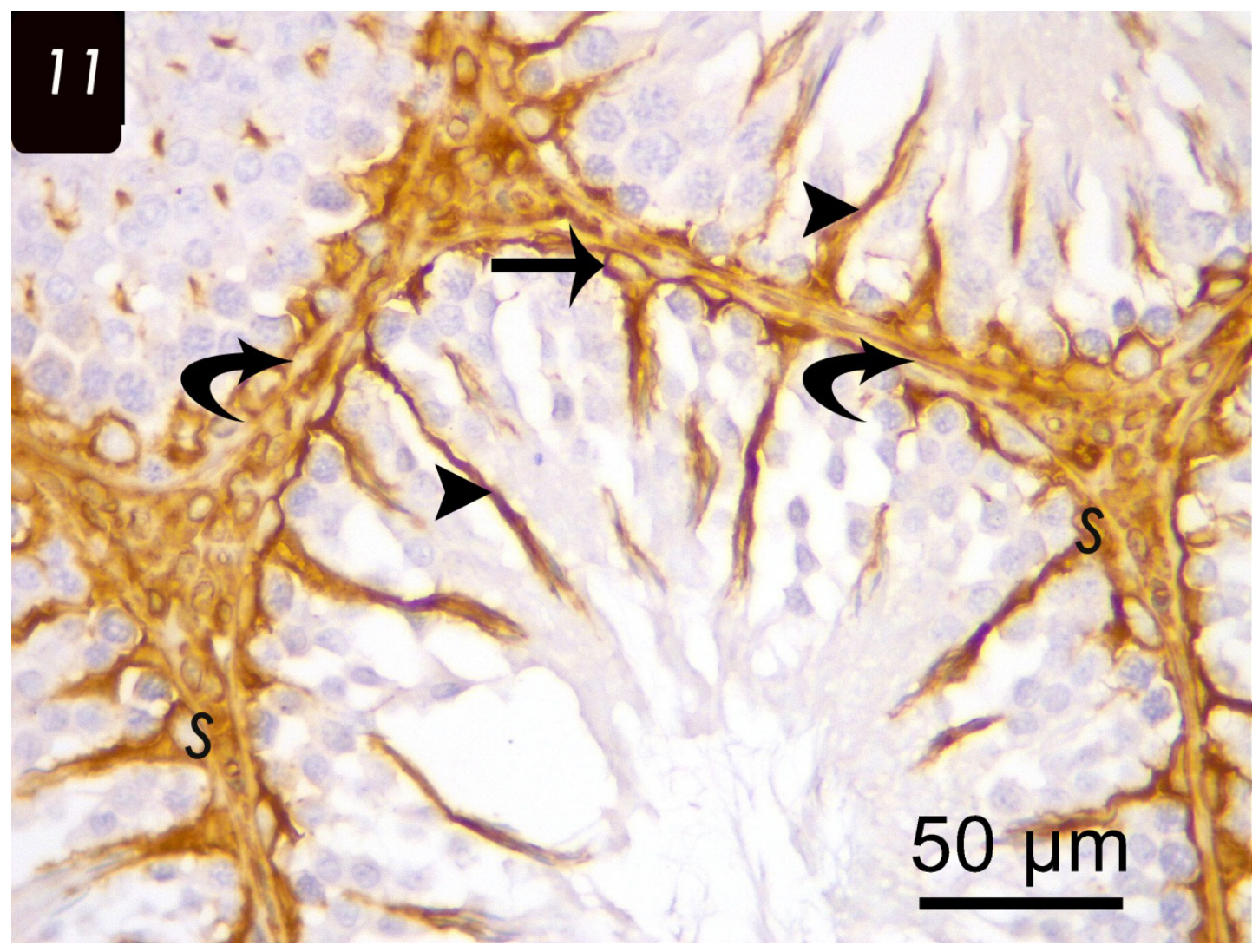

Fig. 11: Aphotomicrograph of a section in testicular tissue of adult albino rat in paracetamol and curcumin treated group shows relative preservation of number of positively stained Sertoli cells (S), perinuclear positivity (arrow), continuously extended positive cytoplasmic extensions (arrow head) and regular basal lamina (curved arrow). (Vimentin immunohistochemistry, Scale bar: $50 \mu \mathrm{m}$ ) 

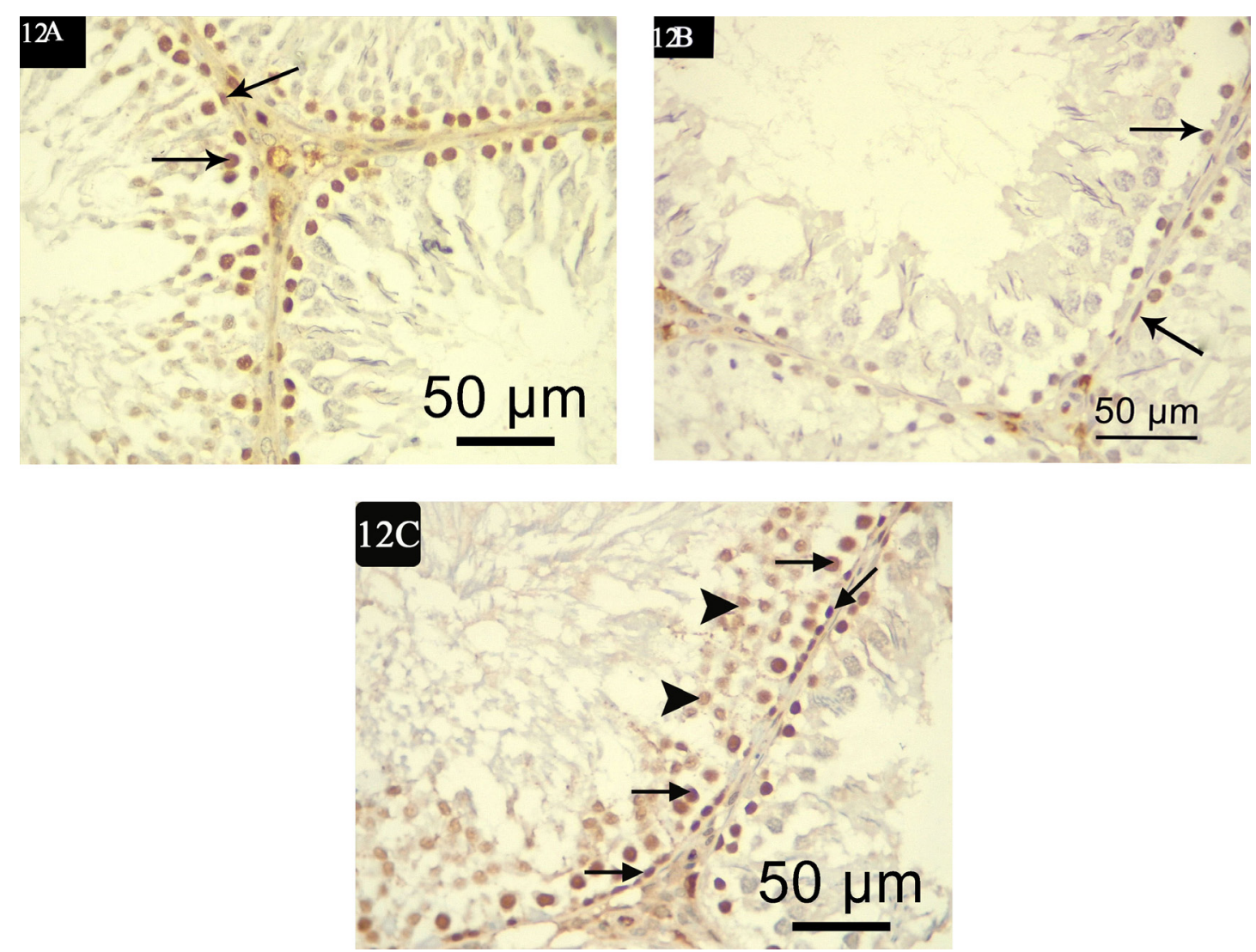

Fig. 12: Photomicrographs of sections in testicular tissue (PCNA immunostaining) showing, (12A) control group with positive immunostaining (brown nuclear reaction) in most of the basal germ cells in the seminefirous tubules (arrows). (12B) paracetamol treated group with few immunopositive germ cells (arrows). (12C) paracetamol and curcumin treated group has more positive basal germ cells (arrow), other mild positive germ cells (arrow head). (PCNA immunostaining, Scale bar: $50 \mu \mathrm{m}$ )

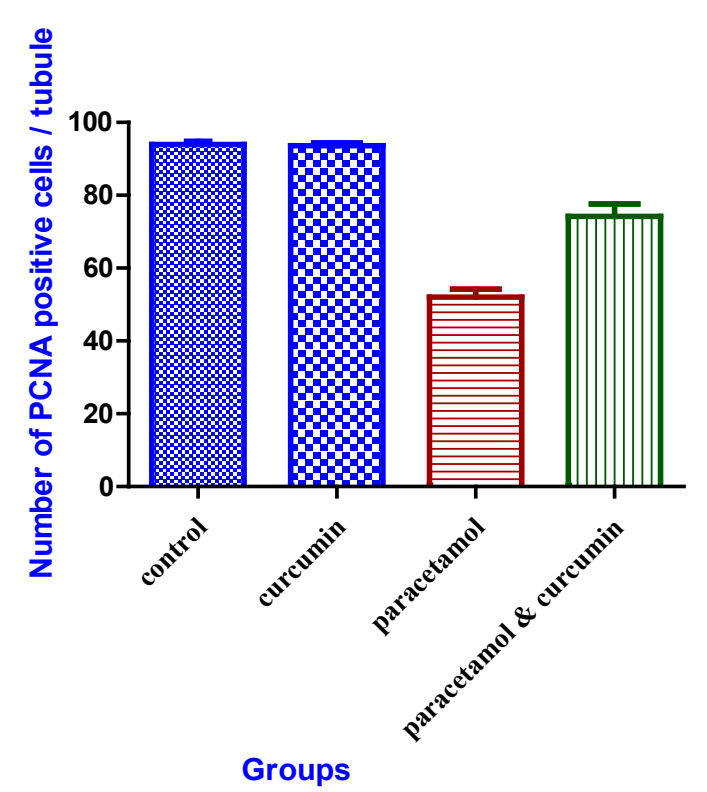

Fig. 13: Bar chart showing the number of PCNA strong positive cells/ tubule among groups

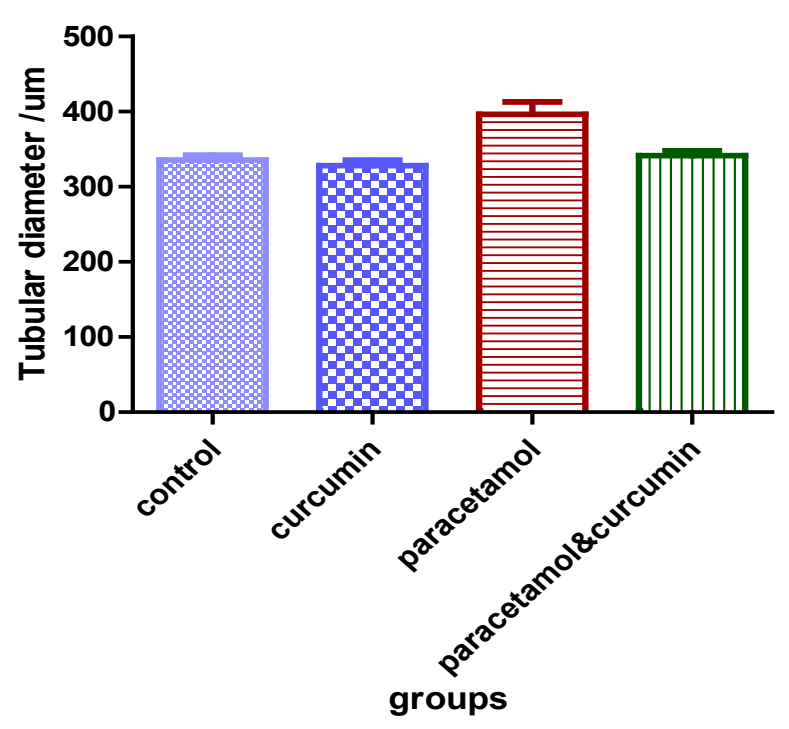

Fig. 14: Bar chart showing the tubular diameter $(\mu \mathrm{m})$ among different groups 


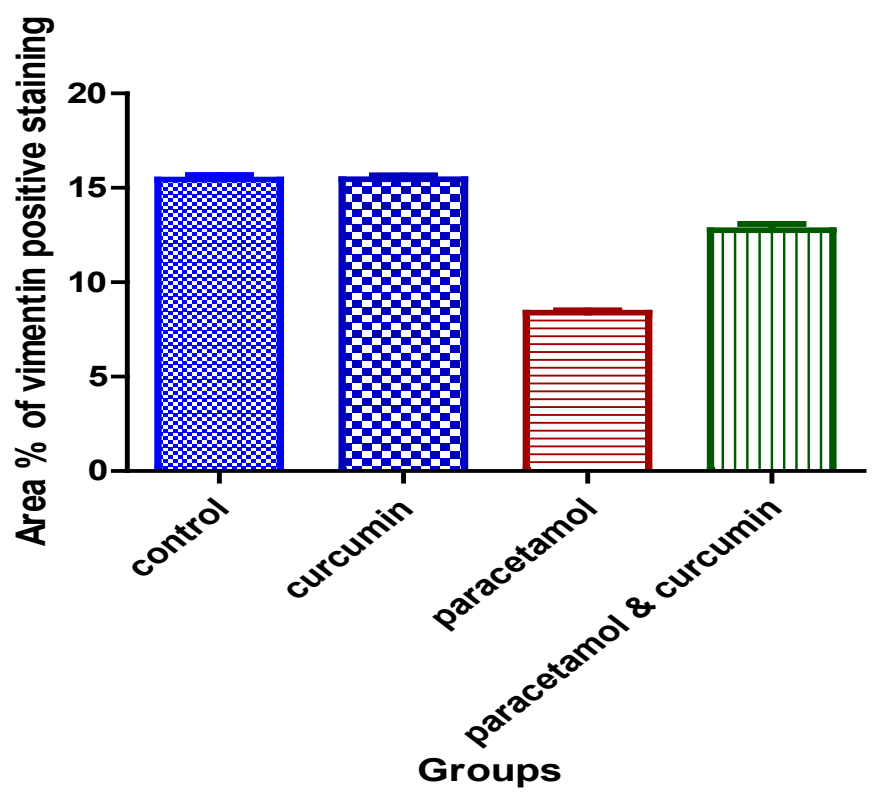

Fig. 15: Bar chart showing the area percentage of vimentin positive staining cells among different groups

Table 1: Means and SE of the body weight,testicular weight,serum testosterone level, Oxidative stress markers sperm count and sperm motility among groups

\begin{tabular}{|c|c|c|c|c|}
\hline Parameter Mean \pm SEM & Control group & Curcumin Group & Paracetamol group & Paracetamol and Curcumin group \\
\hline Body weight & $195.3 \pm 0.6635^{\mathrm{a}}$ & $195.3 \pm 0.6635^{\mathrm{a}}$ & $192.0 \pm 0.6890^{\mathrm{a}}$ & $192.0 \pm 0.7454^{\mathrm{a}}$ \\
\hline Testicular Weight (g) & $1.305 \pm 0.006708^{\mathrm{a}}$ & $1.303 \pm 0.006839^{\mathrm{a}}$ & $1.275 \pm 0.009804^{\mathrm{a}}$ & $1.280 \pm 0.0104^{\mathrm{a}}$ \\
\hline Serum testosterone $\mathrm{ng} / \mathrm{ml}$ & $3.9150 \pm 0.017^{\mathrm{a}}$ & $3.8840 \pm 0.023^{\mathrm{a}}$ & $1.8020 \pm 0.034^{\mathrm{b}}$ & $2.2860 \pm 0.016^{\mathrm{c}}$ \\
\hline $\mathrm{MDA} \mathrm{nmol} / \mathrm{g}$ tissue & $10.72 \pm 0.2686^{\mathrm{a}}$ & $10.29 \pm 0.2482^{\mathrm{a}}$ & $31.43 \pm 0.9159^{\mathrm{b}}$ & $21.45 \pm 0.2734^{c}$ \\
\hline SOD (U\g tissue) & $3.525 \pm 0.05235^{\mathrm{a}}$ & $3.473 \pm 0.04700^{\mathrm{a}}$ & $1.114 \pm 0.02418^{\mathrm{b}}$ & $2.072 \pm 0.04141^{\mathrm{c}}$ \\
\hline GPx (U\g tissue) & $109.3 \pm 1.790^{\mathrm{a}}$ & $112.5 \pm 1.582^{\mathrm{a}}$ & $79.66 \pm 0.7008^{b}$ & $99.38 \pm 0.9310^{\mathrm{a}}$ \\
\hline Sperm count $(106 / \mathrm{ml})$ & $61.32 \pm 0.3536^{\mathrm{a}}$ & $60.91 \pm 0.4076^{\mathrm{a}}$ & $28.62 \pm 0.3309^{\mathrm{b}}$ & $34.90 \pm 0.2308^{c}$ \\
\hline Sperm motility \% & $30.18 \pm 0.1143^{\mathrm{a}}$ & $30.27 \pm 0.1184^{\mathrm{a}}$ & $19.83 \pm 0.2039^{\mathrm{b}}$ & $21.46 \pm 0.1802^{\mathrm{b}}$ \\
\hline
\end{tabular}

Data expressed as mean $\pm \mathrm{SE}$, Groups with different letters are statistically significant $(P<0.05)$

Table 2: Mean and SE of the number of PCNA strong positive cells/tubule and Tubular diameter and area percentage of vimentin positive staining among groups

\begin{tabular}{|c|c|c|c|c|}
\hline parameter & Control & curcumin & paracetamol & Paracetamol and curcumin \\
\hline $\begin{array}{c}\text { The number of PCNA } \\
\text { strong positive cells /tubule } \\
\text { Mean } \pm \text { SEM }\end{array}$ & $93.92 \pm 0.86^{\mathrm{a}}$ & $93.62 \pm 0.79^{\mathrm{a}}$ & $52.00 \pm 2.2^{\mathrm{b}}$ & $74.23 \pm 3.4^{\mathrm{c}}$ \\
\hline $\begin{array}{c}\text { Tubular diameter } \\
\text { Mean } \pm \text { SEM }\end{array}$ & $335.7 \pm 6.151^{\mathrm{a}}$ & $328.1 \pm 7.089^{\mathrm{a}}$ & $396.3 \pm 16.66^{\mathrm{b}}$ & $341.3 \pm 6.276^{\mathrm{a}}$ \\
\hline $\begin{array}{l}\text { Area percentage of } \\
\text { vimentin positive staining }\end{array}$ & $15.45 \pm 0.2318^{\mathrm{a}}$ & $15.46 \pm 0.2036^{\mathrm{a}}$ & $8.391 \pm 0.1164^{\mathrm{b}}$ & $12.77 \pm 0.3225^{\mathrm{c}}$ \\
\hline
\end{tabular}




\section{DISCUSSION}

Paracetamol is a synthetic, nonopioid, act as antipyretic and analgesic. Its role as an antipyretic drug attributed to its effect on heat-regulating center in the hypothalamus ${ }^{[2]}$. Toxicity of paracetamol can be caused from usual use; this may be due to different degrees of enzymes activity in one of the metabolic pathways of paracetamol ${ }^{[25]}$. In the present study, no significant effect of paracetamol on body or testicular weight were detected and this was in agreement with $^{[1]}$ who reported that up to a dose of $1000 \mathrm{mg} / \mathrm{kg}$ paracetamol ,there was no significant difference between control and treated groups according to body weight and testicular weight.

The present study found that the testicular tissue architecture in paracetamol treated group showed many forms of abnormalities as exudate, vacuolations. Some seminiferous tubules were sloughed from lamina propria, had irregular outline and filled with amorphous exudate. Interstitial tissue was wide, containing amorphous material and vacuolations, dilated blood vessels and inflammatory cells infiltration. These results were in consistent with ${ }^{[26]}$. Other seminiferous tubules had sloughed germinal epithelium from basal lamina with spermatogenic cells had dark stained nuclei were noticed. Also, distorted tubules with wide and empty lumina were detected. These were in agreement with ${ }^{[27]}$ who explained destruction of testicular tissue and subsequent infertility by sertoli cell fragmentation, that provide support and nutrition for the spermatic cells, so its destruction result in loss of spermatic cells. In contrast ${ }^{[28]}$ reported that paracetamol is toxic at higher doses. Seminiferous tubule degeneration was characterized by degenerating spermatids and a few germinal epithelial cells in tubular lumens, as with high power results we noticed loss of close relationship of spermatogenic cells, a finding which could impair normal spermatogenesis. Lara et al. ${ }^{[29]}$ reported that the close relationship between germ cells and consequently the intercellular bridges was an important landmark of normal spermatogenesis. In contrast, ${ }^{[30]}$, reported that paracetamol-treated groups of male rats showed no significant histopathological changes of different organs exposed to the higher dose level in comparison to the control group and they attributed the negative toxic effect of paracetamol to its different route of administration. While ${ }^{[31]}$, have explained the deformed seminiferous tubules with a separation of the basal cells in high dose of paracetamole by the covalent binding of some paracetamol metabolites to DNA.

$\mathrm{Also}^{[32]}$, explained This pathogenesis by its oxidant metabolites (N-acetyl-p-benzoquinoneimine, NAPQI), which is usually detoxified by conjugation with reduced glutathione in hepatocyte or conjugated with exogenous antioxidant. Curcumin exhibits a potent scavenger of reactive oxygen and nitrogen species. This explained the improvement of histolgical structure of testis in group of curcumin and paracetamol in the present study which represented by better testicular architecture and restoration of the close relationship of spermatogenic cells and their relationship to sertoli cytoplasmic extensions. In the current study, increased sperms and spermatogenic cells in various stages in spermatogenesis in paracetamol and curcumin group and this result was confirmed by s significant increase in sperm count and motility in paracetamol and curcumin groups. Luangpirom et al., 2012 $2^{[33]}$ and Ratnasooriya \& Jayakody ${ }^{[34]}$ mentioned that the group which received paracetamol exhibited an adverse effect on seminal quality by revealing a significant depletion in total sperm count. While statistically significant increase occurred in paracetamol and curcumin group as the protective role of curcumin was also in accordance with results of [35,36]. According to serum testosterone level there was significant decrease in paracetamol treated group which was in agreement with $^{[33]}$. The level of testosterone slightly increased by curcumin in paracetamol and curcumin group but still lower than control as was reported by ${ }^{[35]}$. Moreover, morphometric analysis of tubular diameter of current study detected increased its diameter significantly than other groups. Creasy, $2001^{[37]}$ reported that dilatation of tubules resulted in thinning and compression of the lining epithelium, which is caused by back pressure from increased volume of fluid within seminiferous tubule lumen. Seminiferous tubular dilatation with its sequel of atrophy could be resulted from a number of chemicals, including the fungicide carbendazim, a PDE4 inhibitor, a leukotriene inhibitor, and endothelin antagonists. In the present study, the histopathological results, testosterone level and sperm analysis were supported by results of PCNA immunoreactivity of testicular tissue and morphometric count of strongly positive stained PCNA cells, as PCNA reactivity was found to be highest in active tubules, particularly in cells which had DNA replication as the spermatogonia and primary spermatocytes. Similar findings were determined in the testis samples of curcumin administered groups. In the paracetamol group, results showed very few positive cells to PCNA, while there was mild improvement in groups of paracetamol administered curcumin observed by increased number of positive cells but still fewer than control group. These findings were also in agreement with ${ }^{[38]}$ who found decreased positive reaction which was indicating lowered proliferation (measured by PCNA) and an increased apoptosis in the seminiferous tubule. These findings were proved by statistic results of number of PCNA positive cells in different groups as there were significant decrease among treated group. in accordance to ${ }^{[39]}$ who said that, PCNA was detected in the mitotically dividing spermatogonia. In the present study, paracetamol and curcumin group showed faint positive spermatogenic cells for PCNA as it can be positively detected during DNA repair as reported by ${ }^{[40]}$.

According to vimentin immunoreactivity, In control group there was positive staining of vimentin in Sertoli cells either located around the nucleus and extended to the apical region of Sertoli cells, as well as its extension which extended between spermatogonia and primary spermatocytes. (El Ghamrawy et al 2014) ${ }^{[24]}$ found that 
middle part and apices of Sertoli cell walls as well as the adjoining germ cells and spermatozoa showed positive vimentin immunostaining. This immunoreactivity staining decreased in paracetamol administrated group but it improved in group which was given curcumin with paracetamol. The adverse effect of this decline in vimentin expression in testicular tissue injury was due to the collapse of vimentin filaments away from cell membrane of Sertoli cell. This could result in detachment of spermatogenic cells, then the detached cells would undergo apoptosis because of loss of the support and nutrition provided by Sertoli cells ${ }^{[41]}$ and this was represented in the present study by high power histopathological results which showed close relations of spermatogenic cells to each other and to sertoli cytoplasmic extensions in paracetamol and curcumin group but conversely loss of these relations in paracetamol treated group. El Ghamrawy et al., 2014 ${ }^{[24]}$ concluded that the Sertoli cell vimentin filaments play an important role in the maintenance of spermatogenesis, where the damage and restoration of spermatogenesis are related to the disintegration or recovery of these filaments.

Also Spermatozoa have abundant poly unsaturated fatty acids, which are more liable for lipid peroxidation by $\operatorname{ROS}^{[42]}$. Lipid malondialdehyde (MDA) level rises in most spermatogenic abnormalities ${ }^{[43]}$. Thus, increased testicular lipid peroxidation, as revealed by the present study which demonstrated significant decrease of the SOD, GPx and increased MDA levels in paracetamol treated group in comparison with control. This means that it increased the oxidative stress in the paracetamol-treated rats. Therefore, the significantly lower levels of MDA in the tissues of curcumin and paracetamol treated groups compared with the paracetamol group indicated decrease of lipid peroxidation. In consistent ${ }^{[44]}$, reported that curcumin subdued lipid peroxidation by quenching oxygen free radicals and by improving the activity of endogenous antioxidant enzymes, SOD, CAT, glutathione peroxidase and glutathio-s-transferase ${ }^{[45]}$. Moreover ${ }^{[46]}$, reported that paracetamol revealed significantly elevated incidences of chromatid breaks due to oxidation and the use of natural antioxidants can protect DNA from damage so increase sperm quality and number.

\section{CONCLUSION}

In conclusion, the present study revealed that curcumin; in particular, is effective in reducing paracetamol testicular toxicity, by ameliorating pathological changes and restoring to a great extent the normal testicular tissue architecture, balancing tissue oxidative state and increasing sperm number Thus, curcumin could afford a feasible and useful food based approach for improving male fertility. Moreover, Clinical application and therapeutic efficacy of curcumin need further investigations and more research to guide its optimal use.

\section{ABBREVIATIONS}

ACMP (Acetaminophen), H (Haematoxylin),
E (Eosin), PCNA (proliferative cell nuclear antigen), SOD (superoxide dismutase), ANOVA (analysis of variance), MDA (malondialdehyde).

\section{CONFLICTS OF INTEREST}

There are no conflicts of interest.

\section{REFRENCES}

1. Venkatesan, P., \& Deecaraman, M. (2014). Subacute toxicity studies of acetaminophen in Wistar rats. Int J Pharm Bio Sci, 5(1), 629-639.

2. Kett, D., Breitmeyer, J., Ang, R., \& Royal, M. (2011). A randomized study of the efficacy and safety of intravenous acetaminophen vs. intravenous placebo for the treatment of fever. Clinical Pharmacology \& Therapeutics, 90(1), 32-39.

3. Daly, F. F., O'malley, G. F., Heard, K., Bogdan, G. M., \& Dart, R. C. (2004). Prospective evaluation of repeated supratherapeutic acetaminophen (paracetamol) ingestion. Annals of emergency medicine, 44(4), 393-398.

4. Ekaluo, U. B., Ikpeme, E. V., \& Udokpoh, A. E. (2009). Sperm head abnormality and mutagenic effects of aspirin, paracetamol and caffeine containing analgesics in rats. Int. J. Toxicol, 7, 1-9.

5. Boekelheide, K. (2005). Mechanisms of toxic damage to spermatogenesis. JNCI Monographs, 2005(34), 6-8.

6. Khorsandi, L., \& Orazizadeh, M. (2008). Protective effect of Curcuma longa extract on acetaminophen induced nephrotoxicity in mice. Daru, 16(3), 155-159.

7. Elsayed, A. S. I. (2016). The curcumin as an antioxidant natural herb with emphasize on its effects against some diseases. International Journal of Applied Biology and Pharmaceutical Technology, 7, 26-40.

8. Sudjarwo, S. A., Sudjarwo, K. E., \& Sudjarwo, G. W. and Koerniasari (2011). Mechanisms of endothelial cell protection by curcumin in hypercholesterolemia. Journal of Applied Pharmaceutical Science, 1(10), 32.

9. Zorofchian Moghadamtousi, S., Abdul Kadir, H., Hassandarvish, P., Tajik, H., Abubakar, S., \& Zandi, K. (2014). A review on antibacterial, antiviral, and antifungal activity of curcumin. BioMed research international, 2014.

10. Perrone, D., Ardito, F., Giannatempo, G., Dioguardi, M., Troiano, G., Lo Russo, L., Lo Muzio, L. (2015). Biological and therapeutic activities, and anticancer properties of curcumin. Experimental and therapeutic medicine, 10(5), 1615-1623. 
11. Jurenka, J. S. (2009). Anti-inflammatory properties of curcumin, a major constituent of Curcuma longa: a review of preclinical and clinical research. Alternative medicine review, 14(2).

12. Farghaly, H. S., \& Hussein, M. A. (2010). Protective effect of curcumin against paracetamolinduced liver damage. Australian Journal of Basic and Applied Sciences, 4(9), 4266-4274.

13. Darney, K.J., Jr,Zirkin, B.R. ,Ewing, L.L.(1996). Testosterone autoregulation of its biosynthesis in the rat testis : inhibition of 17 alpha- hydroxylase activity . J Androl. ;17(2):137-42.

14. Lapenna, D., Ciofani, G., Pierdomenico, S. D., Giamberardino, M. A., \& Cuccurullo, F. (2001). Reaction conditions affecting the relationship between thiobarbituric acid reactivity and lipid peroxidesin human plasma. Free Radical Biology and Medicine, 31(3), 331-335.

15. Arenas-Ríos, E., León-Galván, M. A., Mercado, P. E., \& Rosado, A. (2005). Superoxide dismutase, catalase, and glutathione peroxidase during epididymal maturation and prolonged storage of spermatozoa in the Mexican big-eared bat (Corynorhinus mexicanus). Canadian journal of zoology, 83(12), 1556-1565

16. Pascual, P., Martinez-Lara, E., Barcena, J. A., López-Barea, J., \& Toribio, F. (1992). Direct assay of glutathione peroxidase activity using highperformance capillary electrophoresis. Journal of Chromatography B: Biomedical Sciences and Applications, 581(1), 49-56.

17. Eisenberg, M. L., Murthy, L., Hwang, K., Lamb, D. J., \& Lipshultz, L. I. (2012). Sperm counts and sperm sex ratio in male infertility patients. Asian journal of andrology, 14(5), 683.

18. Lucio, R. A., Tlachi-López, J. L., Eguibar, J. R., \& Ågmo, A. (2013). Sperm count and sperm motility decrease in old rats. Physiology \& behavior, 110, 73-79.

19. Carpenter, J.W., editor (2005) . Exotic Animal Formulary. 3rd Ed. St. Louis: Elsevier Saunders.

20. Fish, R.E., Brown M.J., Danneman P.J., Karas A.Z., editors (2008). Anesthesia and Analgesia in Laboratory Animals. 2nd Ed. New York: Academic Press.

21. Bancroft, J. D., \& Gamble, M. (Eds.). (2008). Theory and practice of histological techniques. Elsevier health sciences.

22. Ali, I. K. A., Kadhim, K. K., \& Al-salihi, A. R. (2016). Histological and immunohistochemical comparison of mature rat testes with glycerol, propanediol and dimethylsulphoxide as cryoprotectants. Adv. Anim. Vet. Sci, 4(1), 35-45.
23. Abdel-Dayem, M. (2009). Histological and immunohistochemical changes in the adult rat testes after left experimental varicocele and possible protective effects of resveratrol. Egypt $\mathrm{J}$ Histol, 32(1), 81-90.

24. ElGhamrawy, T. A., Helmy, D., \& Elall, H. F. A. (2014). Cadherin and vimentin immunoexpression in the testis of normal and induced infertility models of albino rats. Folia morphologica, 73(3), 339-346.

25. Vuppalanchi R, Liangpunsakul S, Chalasani N (2007). "Etiology of newonset jaundice: how often is it caused by idiosyncratic drug-induced liver injury in the United States?" Am. J. Gastroenterol. 102(3):558-62.

26. Hassan, N. A. (2013). Toxic effects of paracetamol on male reproductive system of adult rabbits. International Journal of Pharma and Bio Sciences, 4(1), 806-821.

27. GO, Q. S. W. O. (2014). Cytological and Histological Effect of Paracetamol on the Testis and Liver in Albino Mice Mus musculus. Journal of Zankoy Sulaimani-Part A, 16, 4.

28. Grypioti, A., Theocharis, S., Papadimas, G., Demopoulos, C., Papadopoulou-Daifoti, Z., Basayiannis, A., \& Mykoniatis, M. (2005). Platelet-activating factor (PAF) involvement in acetaminophen-induced liver toxicity and regeneration. Archives of toxicology, 79(8), 466-474.

29. Lara, N. L., Costa, G. M., Avelar, G. F., Lacerda, S. M. S. N., Hess, R. A., \& de França, L. R. (2018). Testis Physiology-Overview and Histology. Reference Module in Biomedical Sciences.

30. Payasi, A., Chaudhary, M., Singh, B. M., Gupta, A., \& Sehgal, R. (2010). Sub-acute toxicity studies of paracetamol infusion in albino wistar rats. Platelets, $10,105 \mathrm{cmm}$.

31. Yano, C. L., \& Dolder, H. (2002). Rat testicular structure and ultrastructure after paracetamol treatment. Contraception, 66(6), 463-467.

32. Yang, J., Meyers, K. J., van der Heide, J., \& Liu, R. H. (2004). Varietal differences in phenolic content and antioxidant and antiproliferative activities of onions. Journal of agricultural and food chemistry, 52(22), 6787-6793.

33. Luangpirom, A., Kourchampa, W., \& Junaimuang, T. (2012). Attenuating effect of Allium ascalonicum L. on paracetamol induced seminal quality impairment in mice. Journal of Medicinal Plants Research, 6(13), 2655-2659. 
34. Ratnasooriya, W., \& Jayakody, J. (2000). Longterm administration of large doses of paracetamol impairs the reproductive competence of male rats. Asian journal of andrology, 2(4), 247-255.

35. Roshankhah, S., Salahshoor, M., Aryanfar, S., Jalili, F., Sohrabil, M., \& Jalili, C. (2017). Effects of curcumin on sperm parameters abnormalities induced by morphine in rat. Journal of Medical and Biomedical Sciences, 6(2), 1-10.

36. Panchal, S., \& Verma, R. J. (2016). Effect of diethanolamine on testicular steroidogenesis and its amelioration by curcumin. Asian Pacific Journal of Reproduction, 5(2), 128-131.

37. Creasy, D. M. (2001). Pathogenesis of male reproductive toxicity. Toxicologic pathology, 29(1), 64-76.

38. Cavalcante, F. S., Aiceles, V., Moraes, D. d. F. S., Alves-Pereira, J. L., Faria, T. S., \& Ramos, C. d. F. (2014). The testis of the mice C57/BL6 offspring in adulthood have alterations due to maternal caffeine consumption. Acta cirurgica brasileira, 29(1), 16-23.

39. Chapman, D. L., \& Wolgemuth, D. J. (2002). Expression of proliferating cell nuclear antigen in the mouse germ line and surrounding somatic cells suggests both proliferationdependent and-independent modes of function. International Journal of Developmental Biology, 38(3), 491-497.

40. Essers, J.,Theil, A.F., Baldeyron,C.,VanCasppell,
W.A.,Houstmuller, A.B.,Kanaar,R., \&Vermeulen, W.(2005).Nuclear Dynamics of PCNA in DNA replication and repair MOL.Cell.Biol.25(21):93509359.doi:10.1128/MCB.25.21.9350-9359.2005

41. Alam, M., Ohsako, S., Tay, T., Tsunekawa, N., Kanai, Y., \& Kurohmaru, M. (2010). Di (n-butyl) phthalate induces vimentin filaments disruption in rat sertoli cells: a possible relation with spermatogenic cell apoptosis. Anatomia, histologia, embryologia, 39(3), 186-193.

42. El-Sweedy, M., Abdel-Hamid, N., El-Moselhy, M. (2007).The role of a mixture of green tea, turmeric and chitosanin the treatment of obesity-related testicular disorders. J.Appl. Biomed., 5: 131-138.

43. Sharma, R.K. \& Agarwal, A. (1996). Role of reactive oxygen species in male infertility. Urology., 48:835-850.

44. Srinivasan, K., (2005). Role of spices beyond food flavouring: nutraceuticals with multiple health effects . Food Rev Int., 21: 167-88.

45. Manikandana, P., M. Sumitra, S. Aishwarya, B.M. Manohar, B. Lokanadam \& R. Puvanakrishnan,( 2004). Curcumin modulates free radical quenching in myocardial ischaemia in rats. Int J Biochem Cell Biol., 36: 1967-80.

46. Salah S. H.1 , Abdouh S.1, Hodaf Boolesand1 \& Abdel Rahim E. A. (2012). Effect of Zingiber Officinale on paracetamol-induced genotoxicity in male rats. Journal of Medicinal Plants Research , 6(41), 5425-5434. 
الملخص العربى

\title{
الدورالمحتمل للكركم في مواجهة التغيرات الناتجه عن البار اسيتامول في خصيه الجرذ إذ إنها الابيض البالغ (دراسه نسيجية ومناعة كميائية و كيميائية)
}

\author{
هبه اسـامه محمد - رشا محمد صبري

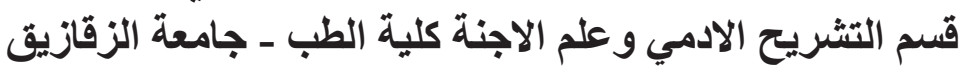

المقدمه: يعتبر البار اسيتامول من اكثر الادويه استخداما لاعتقاد الكثير من الناس انها غير ضاره. كما أن الكركم له استخدامات دو ائيه متعدده كمضاد للبكتريا و الفيروسات و الفطريات و الاور ام. الهذف من هذه الار اسة: هذه الدر اسه اجريت لتقييم التاثير ات الهستو باثولوجيه و البيوكيميائيه للبار اسيتامول على نسيج الخصيه و لاي مدى يستطيع الكركم ان يحميها من هذه التغير ات. المواد والطرق المستخدمة: أجريت هذه الدر اسه على ثمانية و عشرين جرذ ذكر ابيض بالغ وتم تقسيمهم بالتساوي الى هلى اربع مجمو عات كالتالي: المجموعه الاولى الضابطه: تم تقسيمهم الى (أكب تتاولو ا ماء مقطر وزيت ذره على الترنيب)،

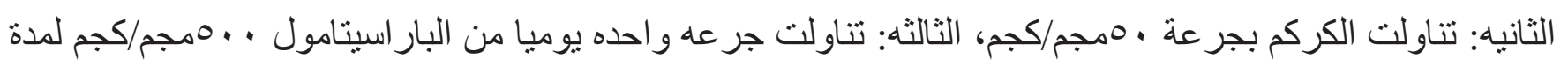
خمس ايام، الر ابعه: تناولت الكركم قبل البدء في العلاج بالبار اسيتامول بجر عة ـ مدجم/كجم واستمرت لمدة عشر ايام قبل البدء في تناول البار اسيتامول، ثم تناولت الكركم بنفس الجرعه مع البار اسيتامول لمدة خمس ايام اخرى.في هذه الدر اسه تم عد الحيو انات المنويه ودر اسة التركيب الهستوباثولوجي و الهستوكيميائي المناعي و البيوكيميائي و القياسات

الثكلية (المورفو ميتري) و التغير ات الكيميائيه لجميع الجرذان.

النتائج: تسبب عقار البار اسيتامول في فقد النظم النسيجي في خصية الفئر ان تمثل في فقد انتظام وقلة عدد طبقات الخلايا الجرثومية المبطنه لانابيب الخصيه و اتساع الفر اغات فيما بين انابيب الخصية و اتساع المسافات بين الخلوية بين الخلايا الجرثومية. كما لوحظ نقص في عدد خلايا السيرتولي المصبو غه بالفيمنتين و اعداد الخلايا المصبو غه بمضاد PCNA وزيادة الضغط الاكسيدي. كما وجد ان كل هذه التغير ات قد تحسنت في المجمو عه التي تناولت الكركم قبل و اثناء تناول البار اسيتامول. الخلاصة: الكركم له تاثير فعال في تقليل التاثير السمي للبار اسيتامول علي خصيه الجرذ الابيض البالغ وذلك بتقليل اختلال التوازن الاوكسيدي وتحسين التغيرات الهستوباتولوجيه و الهستوكيميائيه المناعيه التي احدثت باعطاء البار اسيتامول وتحسين وظيفة الخصيه ممايجعله يؤخذ في الاعتبار للانسان. 